\title{
Assessment of urban groundwater quality using Piper trilinear and multivariate techniques: a case study in the Abuja, North-central, Nigeria
}

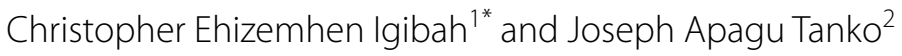

\begin{abstract}
Background: Groundwater pollution ensuing from ion exchange, weathering, agricultural and anthropogenic activities is on the rise in Nigeria. Since groundwater is used for domestic purposes, there is need for routine investigation. Findings on hydrochemistry of the groundwater components is essential for efficient and viable management. As a result, 25 Abuja water samples were collected for microbial and chemical analyses using standard methods. The cations, anions, soluble ions, trace elements, and heavy metal were obtained and compared with WHO standards.

Results: The Discriminant analysis results shown that the parameters such as hydrogen ion concentration $(\mathrm{pH})$, temperature $(\mathrm{T})$, alkalinity $(\mathrm{Alk})$, dissolve silica $\left(\mathrm{SiO}_{2}\right)$, and cations such as calcium $\left(\mathrm{Ca}^{2+}\right)$, potassium $\left(\mathrm{K}^{+}\right)$, as well as anions such as carbonates $\left(\mathrm{CO}_{3}{ }^{2-}\right)$, fluoride $\left(\mathrm{F}^{-}\right)$, nitrates $\left(\mathrm{NO}_{3}{ }^{-}\right)$, and heavy metal $(\mathrm{Mn})$ were within the WHO guideline values for drinking water in all the samples for both seasons. $\mathrm{Na}^{+}, \mathrm{SO}_{4}{ }^{2-}, \mathrm{EC}, \mathrm{Mg}^{2+}, \mathrm{TDS}, \mathrm{Fe}^{2+}, \mathrm{HCO}_{3}{ }^{-}, \mathrm{F}^{-}, \mathrm{TH}^{2}$ and $\mathrm{Cl}^{-}$contents exhibited the most violation of drinking water standards with percent violations of $100,76,64,56,56$, $44,40,40,36$ and $24 \%$, respectively. The highest level of significant correlation was found to exist between $\mathrm{K}^{+}$and $\mathrm{EC}$ $(r=0.77, a=0.05)$. Four hydro chemical clusters were identified from Hierarchical cluster analysis (HCA) with clearly partitioned water quality. Series and time series plot reveals TDS concentration value between 1200 and $2100 \mathrm{mg} / \mathrm{l}$, has the highest with the mean and SD are 1433.76 and 459.38, respectively. Further analysis revealed that 16,36 and $48 \%$ of the samples were the $\mathrm{Ca}-\mathrm{Cl}, \mathrm{Na}-\mathrm{Cl}$, and Mixed types, respectively.
\end{abstract}

Conclusion: Groundwater in the Abuja district is mainly hard to very hard, slightly acidic in nature, polluted by ion exchange, agricultural activities, anthropogenic activities, and weathering. Therefore, there is also need for routine monitoring of groundwater in Abuja.

Keywords: Discriminant analysis, Chloride, Violation, Anthropogenic, Abuja, Nigeria

\section{Introduction}

Groundwater is the main source of water for drinking, domestic, industrial and agricultural purposes in many nations. The population growth of many countries has led to enormous scale of groundwater developments in some regions. Likewise, municipal development also triggered a great demand on groundwater resources in

\footnotetext{
*Correspondence: igibahchrist1@gmail.com; lightjesuniyi@yahoo.com 1 Department of Civil Engineering, University of Abuja, Abuja, FCT, Nigeria Full list of author information is available at the end of the article
}

semi-arid as well as arid zones of the world and Nigeria, whereas putting these resources at high risk to contagion (Li 2016; Etteieb et al. 2017). Therefore, there is need for studies on how groundwater will be managed. For effectiveness, the management and assessment of groundwater resources need an understanding of hydrogeochemical and hydrogeological features of the aquifer (Azhar et al. 2015). Since, Hydrogeochemical procedures that are responsible for inconsistent of the chemical composition of groundwater fluctuate with respect to space and time, thus the chemical 
physiognomies of groundwater which plays an essential role in classifying and evaluating the water quality need to be constantly scrutiny (Cao et al. 2016; Li et al. 2013). Groundwater quality depends on several factors such as recharge water quality, geology, grade of chemical weathering of the different rock types, and water-rock interface (Emenike et al. 2017; Aly 2015). Additionally, several recent studies on groundwater quality have been conducted. Many of the study centered on evaluating the natural concentrations of several metals and ions in groundwater, to segregate natural and anthropogenic sources that interrupt groundwater quality, and found interfaces that take place in the aquifer (e.g., Chen et al. 2016; Cao et al. 2016; Ehya and Marbouti 2016; Gu et al. 2015). The findings of groundwater previous studies (Arulbalaji and Gurugnanam 2017; Cao et al. 2016; Ojekunle et al. 2016; Li et al. 2015) concludes that quick population growth, unplanned municipal development, agricultural activities, insufficient hydrogeochemical knowledge, and poor groundwater quality management, are some major factors responsible for groundwater quality control.

Nevertheless, the hydrogeological and hydrogeochemical features of the aquifer has not been carefully studies. Despite, groundwater serve as only source of water to both rural and cities for drinking, agriculture, domestic, industrial and irrigation uses in Abuja, a city in North-central Nigeria. In study area, agriculture is the most significant commercial activity affecting the changes in groundwater quality by anthropogenic effect. Hence, hydro chemical analysis of the groundwater has become a high priority issue. The findings of this study will heighten public understanding of the groundwater composition, which can contribute to effective management of groundwater by water management authorities. Thus main aims of the present study is (1) to ascertain the main hydro geochemical procedures (2) to determine the groundwater quality and (3) to delimit areas where groundwater is unsuitable or fit for drinking, cooking, irrigation, industrial and agricultural purpose.

\section{Materials and methods}

\section{Study area}

The sampling sites for the study were in Abuja - the centre and capital of Nigeria. Abuja is defined by Aso rock, a 400-m monolith at the center, and near Zuma Rock, a 792-m monolith, north of the city on Kaduna express road. It lies between latitude $9.4^{\circ} \mathrm{N}$ and longitude $7.29^{\circ}$ E. The population of Abuja is estimated at 6000,000 with an annual growth rate of $35 \%$, retain position as the African fastest growing city (Enitan et al. 2018). The city is served by the Nnamdi Azikiwe International Airport, and is the administrative and political centre of Nigeria. Other neighboring cities that share common boundaries with Abuja include Kaduna, Lokoja, Keffi, and Mandalla.

\section{Sample collection}

In this study, to evaluate the quality of groundwater, 25 groundwater samples were collected from different locations (P1-P25) in Abuja North-central (Fig. 1) during March to July 2018, analyzed for various chemical parameters as described by the American Public Health Association (APHA 2005), examined and compared with World Health Organization (WHO) water quality standards (WHO and UNICEF 2014). These parameters include hydrogen ion concentration $(\mathrm{pH})$, total hardness $(\mathrm{TH})$, temperature $(\mathrm{T})$, electrical conductivity $(\mathrm{EC})$, alkalinity (Alk), total dissolved solids (TDS), dissolve silica $\left(\mathrm{SiO}_{2}\right)$, and significant cations such as sodium $\left(\mathrm{Na}^{+}\right)$, calcium $\left(\mathrm{Ca}^{2+}\right)$, potassium $\left(\mathrm{K}^{+}\right)$, magnesium $\left(\mathrm{Mg}^{2+}\right)$, and iron $\left(\mathrm{Fe}^{2+}\right)$ as well as anions such as sulphate $\left(\mathrm{SO}_{4}{ }^{2-}\right)$, carbonates $\left(\mathrm{CO}_{3}{ }^{2-}\right)$, chloride $\left(\mathrm{Cl}^{-}\right)$, bicarbonates $\left(\mathrm{HCO}_{3}{ }^{-}\right)$, fluoride $\left(\mathrm{F}^{-}\right)$, nitrates $\left(\mathrm{NO}_{3}{ }^{-}\right)$, and heavy metal $(\mathrm{Mn})$. Sensitive water quality parameters such as $\mathrm{pH}$ and EC were measured on site using multiparameter Hanna edge ${ }^{\circledR} \mathrm{HI} 2031$ conductivity metre and a Hanna HI98131 probe. Fe and Mn concentration was measured with the flame absorption spectrophotometer (FAAS) (Phung et al. 2015). $\mathrm{NO}_{3}{ }^{-}$and $\mathrm{SO}_{4}{ }^{2-}$ was measured with spectrophotometer. The $\mathrm{F}^{-}$concentration in the samples was quantified using a calibrated potentiometric ion- selection electrode (HANNA-HI5315) in connection with a specialized water-resistant filtered ORP/pH/ISEmeter (HANNA-HI98191). $\mathrm{Cl}^{-}$levels was measured using argentometric titration while $\mathrm{HCO}^{-}, \mathrm{TH}, \mathrm{Ca}^{2+}$, TA and $\mathrm{CO}_{3}{ }^{2-}$ were analyzed by volumetric method. $\mathrm{SiO} 2, \mathrm{Na}^{+}$, $\mathrm{Mg}^{2+}$, and $\mathrm{K}^{+}$were estimated using standard method laid out by the American Public Health Association (APHA 2005). The correlation of the analytical data were attempted by plotting graphical representation of various kind for the classification of water and to examine the groundwater fitness for utilitarian purposes by discovering different elements on which the chemical physiognomies of water depend. The groundwater fitness for irrigation, drinking, agricultural, industrial and, domestic purposes was assessed by equating the values of various water quality parameters with those of the World Health Organization (WHO and UNICEF 2014) recommendation values for drinking water. Moreover, Standard sampling techniques were employed throughout the study and samples collected were kept, in accordance with stipulated techniques used for clean water before analysis was carried out. Laboratory quality control techniques 


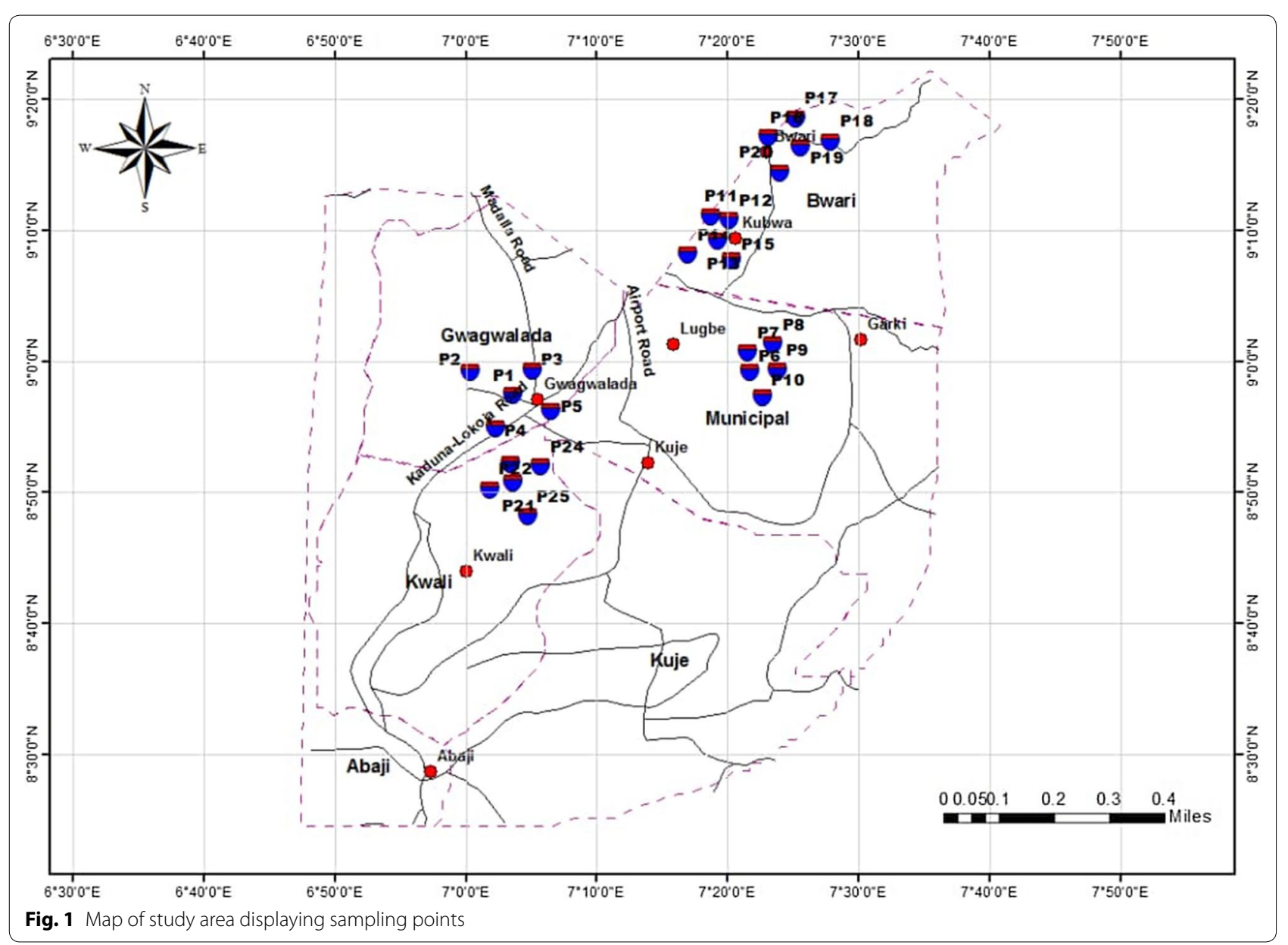

with standard operating processes, standards calibration, and analysis of replicates were applied to guarantee all data quality.

\section{Data treatment and statistical analysis}

Laboratory results were subjected to descriptive statistical analyses. The degree of violation of each water quality parameter was estimated by considering the number of times it exceeded the WHO water quality guidelines. Correlation between parameters was also performed using Pearson's pairwise correlation at 0.05 level of significance. HCA was applied to the parameters as well as the sampling points to classify objects into groups according to their similarity (nearness). Cluster group (CG) of sampling points were used for spatial delineation of water quality. HCA is the most widely used method for classifying a group of data into similar subgroups, beginning with two of the most similar objects and developing higher clusters in a stepwise manner (Khound and Bhattacharyya 2016; Al-Murairi and Abahussain 2014; Jalal et al. 2012). In this paper, Ward's method of linkage and squared Euclidean distance were employed. The
Hierarchical cluster analysis (HCA) method was applied to the 25 water quality parameters using the Statistical Package for Social Sciences (SPSS). Next, Discriminant analysis (DA) was applied to the parameters as well as the sampling points to classify objects into groups according to their similarity (nearness). Clustering of sampling points were employed for spatial delimitation of water quality. HCA is the most common technique for classifying a group of data into related subgroups, starting with two of the most related objects and developing higher clusters in a stepwise manner (Fijani et al. 2017; Jalal et al. 2012). In this study, squared Euclidean distance and ward's method of connection were used. A hydro-chemical classification of the water samples was attempted by using Piperplot-QW for plotting Piper trilinear.

\section{Results and discussion}

\section{Physicochemical parameters of groundwater}

Descriptive statistics of 19 measured variables at 25 sampling sites for the whole sampling period are summarized in Table 1. The results shows that $\mathrm{pH}$ (mean range, 6.60-7.45 mg/l), $\mathrm{NO}_{3}{ }^{-}$(mean range, $0.00-6.16 \mathrm{mg} / \mathrm{l}$ ), $\mathrm{K}^{+}$ 
(mean range, 2.06-9.31 mg/l), $\mathrm{Ca}^{+}$(mean range, 22.01$226.56 \mathrm{mg} / \mathrm{l}$ ) and $\mathrm{Mn}$ (mean range, $0.01-0.10 \mathrm{mg} / \mathrm{l}$ ) is within the permissible levels, while all other parameters exceed average levels set by national guidelines for residential use and other purposes. The non-compliance of water quality parameters degree and WHO drinking water quality standards was calculated as a percentage (\%) of the total number of times a parameter surpassed specified standards shows in Table 2. It was establish that $\mathrm{Na}^{2+}, \mathrm{SO}_{4}{ }^{2-} \mathrm{EC}$, TDS, $\mathrm{Mg}^{2+}, \mathrm{Fe}^{2+}, \mathrm{HCO}_{3}{ }^{-}, \mathrm{F}^{-}, \mathrm{TH}$ and $\mathrm{Cl}^{-}$displayed the most violation of drinking water standards with percent violations of $100,76,64,56,56,44,40$, $40,40,36$ and $24 \%$, respectively.

These results are consistent with (Emenike et al. 2017) who reported that $\mathrm{Na}^{2+}, \mathrm{Mg}^{2+}, \mathrm{Fe}^{2+}$ and $\mathrm{EC}$, exhibited the most violation of drinking water standards with percent violations of $100,52.4,47.6$, and $47.6 \%$, respectively. High levels of $\mathrm{Na}+$ can possibly be outcome of groundwater pollution by sewage, irrigation and salt deposits erosion and sodium-bearing rocks (Achieng et al. 2017). $\mathrm{Cl}^{-}$is a minor constituent earth's crust constituent with a major dissolved constituent of most natural waters can percolate into the groundwater from road salting, agricultural runoff and rocks. $\mathrm{F}^{-}$can occur either artificially or naturally in portable water, and are fascinated to some degree in the bone structure of the tooth enamel and entire body. High level of $\mathrm{F}^{-}$can cause oxidization of water treatment equipment and piping. The high levels of $\mathrm{Fe}^{2+}$ in the Abuja groundwater samples is most likely due to the low water $\mathrm{pH}$ ensuing from the oxidization of water delivery pipes. Though $\mathrm{Fe}^{2+}$ is an important element in human being and is of slight health concern, its existence in water constitutes an irritant (Achieng et al. 2017; Li 2016) noted that high TDS and EC can be ascribed to rainwater infiltration, ion exchange, sediment dissolution and evaporation. TDS level in water reliant on the chemical nature of the water and the aquifer materials solubility through which the water is flowing. The high levels of TDS in the groundwater samples examined should be a great source of anxiety. It has been attested that high levels of TDS could lead to laxative effects and gastrointestinal irritations (Cao et al. 2016; Li et al. 2015). $\mathrm{SO}_{4}{ }^{2-}$ can formed artificially from runoff of fertilized agriculture lands and naturally through soil or rock and other common minerals. High levels of $\mathrm{Mg}^{2+}$ and $\mathrm{SO}_{4}{ }^{2-}$ has been reported causing dehydration (Fingl 1980).

\section{Correlation of physicochemical parameters}

Pearson's correlation coefficients were calculated for each hydrogeological parameters as displayed in Table 3. A significant correlation was found to occur between $\mathrm{Cl}^{-}$and Alk $(\mathrm{r}=0.85, \alpha=0.05)$. Positive and significant correlation was also achieved between $\mathrm{K}^{+}$and EC $(\mathrm{r}=0.77, \alpha=0.05), \mathrm{F}^{-}$and $\mathrm{T}(\mathrm{r}=0.66, \alpha=0.05)$, Ec and Alk $(\mathrm{r}=0.62, \alpha=0.05)$, and anions, such as $\mathrm{HCO}_{3}{ }^{-}$and $\mathrm{SO}_{4}{ }^{2-}(\mathrm{r}=0.56, \alpha=0.05)$.

But when compared with coastal aquifer of Khulna District, Bangladesh (Islam et al. 2017); Rapur area, Andhra Pradesh, South India (Sreedhar et al. 2016); Dongsheng coalfield, Ordos Basin, China (Li et al. 2013). The high correlation coefficient was between $\mathrm{Na}^{+}$and $\mathrm{Cl}^{-}, \mathrm{Ca}^{2+}$ and $\mathrm{SO}_{4} 2$ while Potassium $\left(\mathrm{K}^{+}\right)$and $\mathrm{NO}^{3-}$ were not significantly correlated to any other ions expect each other $(\mathrm{r}=0.511, \alpha=0.05)$.

Emenike et al. (2017) observed that contaminations in limestone, such as $\mathrm{SO}_{4}{ }^{2-}, \mathrm{SiO}_{2}$, and $\mathrm{Cl}^{-}$, become exposed to the water solvent action, as carbonates are liquefied they also pass into solution. This relatively explains the high positive correlation between $\mathrm{HCO}_{3}{ }^{-}$and $\mathrm{SO}_{4}{ }^{2-}$. Similar correlations were obtained (Phung et al. 2015; Jalal et al. 2012) found that the EC finds higher level correlation significance with the water quality parameters, like $\mathrm{K}^{-}$and Alk. Raman and Geetha (2005) discovered that the ground water quality can be projected with sufficient precision just by the measurement of EC only. This offers a means for quicker and easier monitoring of water quality in an area.

\section{Cluster analysis}

Hierarchical cluster analysis (HCA) rendered a dendrogram which classified the 25 sites into four clusters in a convincing way (Fig. 2). The analysis produced four hydro chemical clusters of the study area with physiognomies shown in Table 4. The means concentrations of water quality parameters were compared with WHO standard for drinking water displays in Table 5 . Cluster 1 (C1) comprises parameters ( $\mathrm{pH}, \mathrm{Temp}, \mathrm{Alk}, \mathrm{CO}_{3}{ }^{2-}, \mathrm{NO}^{3-}, \mathrm{F}^{-}$, $\mathrm{K}^{+}, \mathrm{Fe}^{2+}, \mathrm{Ca}^{2+}, \mathrm{Mg}^{2+}, \mathrm{Mn}, \mathrm{SiO}_{2}$ ) in two districts (Kubwa and Bwari), which are mixed urban and rural regions.

$\mathrm{F}^{-}$forms cluster with $\mathrm{pH}$ which is primarily interrelated to the iron-phosphate cluster which is in agreement with findings made by Das and Nag (2017).

Cluster 2 (C2) is a small cluster comprising only one parameter (TDS) in Kwali district where agricultural land use is predominant. Cluster 3 (C3) comprises 5 parameters $\left(\mathrm{EC}, \mathrm{SO}_{4}{ }^{2-}, \mathrm{HCO}_{3}{ }^{-}, \mathrm{Na}^{+}, \mathrm{TH}\right)$ in Lugbe district where urban and industrial sectors are predominant. As reported by Das and Nag (2017), hardness factors such as TH, $\mathrm{Ca}^{2+}, \mathrm{Mg}^{2+}$ are clubbed with EC and TDS. This denotes that for rapid evaluation of water quality, abridged number of monitoring sites in each cluster can serve for spatial evaluation of the water quality of the entire network. Cluster 4 (C4) is also small cluster comprises only one parameter $\left(\mathrm{Cl}^{-}\right)$at Gwagwalada district where natural chlorination is a widespread phenomenon in all kinds of soils of the region. The evidence 


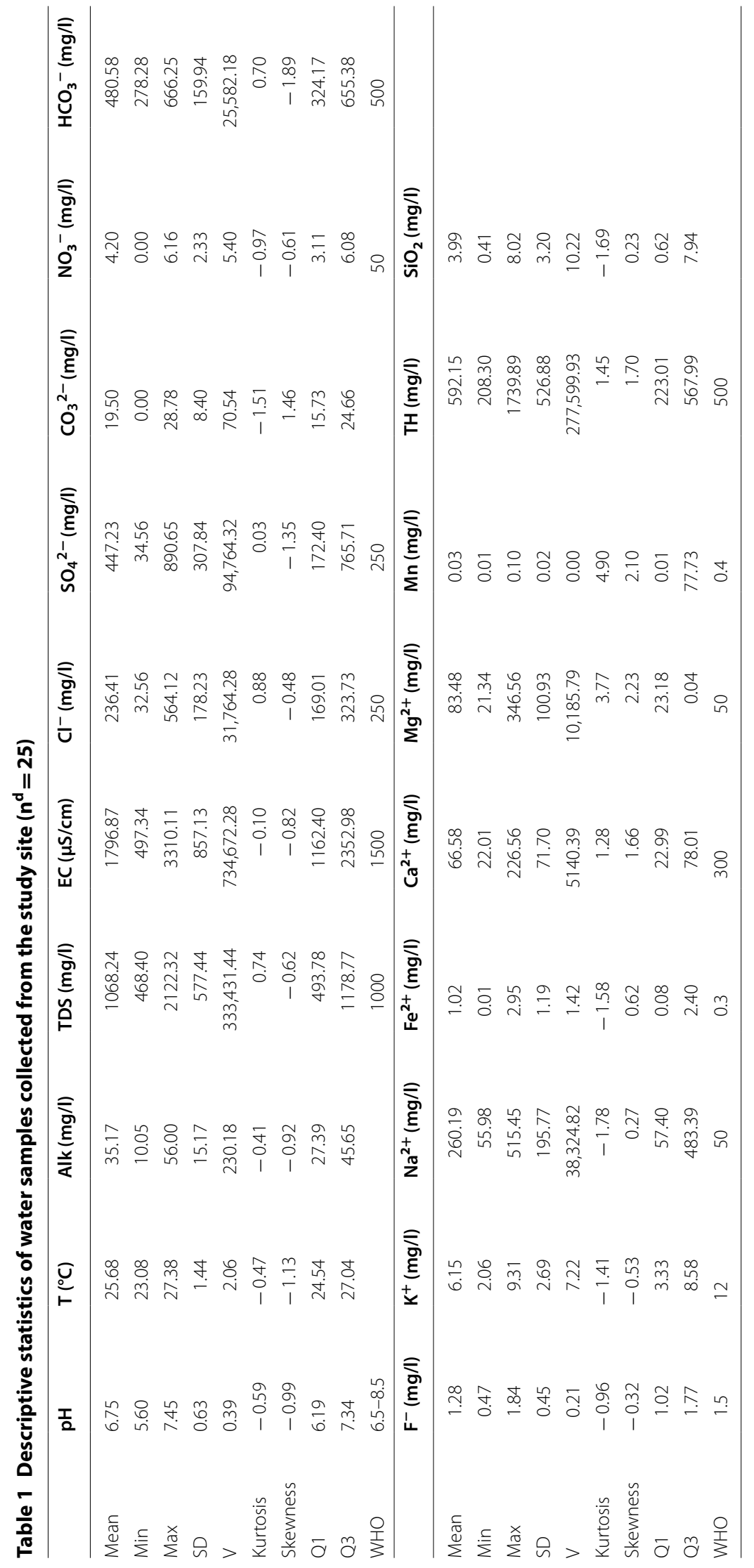


Table 2 Different samples violation values

\begin{tabular}{|c|c|c|c|c|c|}
\hline Parameter & Unit & WHO limit & $\begin{array}{l}\text { Violation } \\
\text { number }\end{array}$ & $\begin{array}{l}\text { Violation } \\
(\%)\end{array}$ & Within (\%) \\
\hline $\mathrm{pH}$ & & $6.5-8.5$ & 0 & 0 & 100 \\
\hline $\mathrm{T}$ & ${ }^{\circ} \mathrm{C}$ & NA & & & \\
\hline AlK & $\mathrm{mg} / \mathrm{l}$ & NA & & & \\
\hline TDS & $\mathrm{mg} / \mathrm{l}$ & 1000 & 14 & 56 & 44 \\
\hline $\mathrm{EC}$ & $\mu S / c m$ & 1500 & 16 & 64 & 36 \\
\hline $\mathrm{Cl}^{-}$ & $\mathrm{mg} / \mathrm{l}$ & 250 & 6 & 24 & 76 \\
\hline $\mathrm{SO}_{4}{ }^{2-}$ & mg/l & 250 & 19 & 76 & 24 \\
\hline $\mathrm{CO}_{3}{ }^{2-}$ & $\mathrm{mg} / \mathrm{l}$ & NA & & & \\
\hline $\mathrm{NO}_{3}^{-}$ & $\mathrm{mg} / \mathrm{l}$ & 50 & 0 & 0 & 100 \\
\hline $\mathrm{HCO}_{3}^{-}$ & $\mathrm{mg} / \mathrm{l}$ & 500 & 10 & 40 & 60 \\
\hline $\mathrm{F}^{-}$ & $\mathrm{mg} / \mathrm{l}$ & 1.5 & 10 & 40 & 60 \\
\hline $\mathrm{K}^{+}$ & $\mathrm{mg} / \mathrm{l}$ & 12 & 0 & 0 & 100 \\
\hline $\mathrm{Na}^{+}$ & $\mathrm{mg} / \mathrm{l}$ & 50 & 25 & 100 & 0 \\
\hline $\mathrm{Fe}^{2+}$ & $\mathrm{mg} / \mathrm{l}$ & 0.3 & 11 & 44 & 56 \\
\hline $\mathrm{Ca}^{2+}$ & $\mathrm{mg} / \mathrm{l}$ & 300 & 0 & 0 & 0 \\
\hline $\mathrm{Mg}^{2+}$ & $\mathrm{mg} / \mathrm{l}$ & 50 & 14 & 56 & 44 \\
\hline$M n$ & $\mathrm{mg} / \mathrm{l}$ & 0.4 & 0 & 0 & 100 \\
\hline $\mathrm{TH}$ & $\mathrm{mg} / \mathrm{l}$ & 500 & 9 & 36 & 64 \\
\hline $\mathrm{SiO}_{2}$ & $\mathrm{mg} / \mathrm{l}$ & NA & & & \\
\hline
\end{tabular}

also proposes an opportunity for designing a prospective spatial sampling stratagem in an ideal manner, leading to a more affordable water monitoring scheme in the Abuja area. The outcomes of this current study tally with the successful application of this method in water quality programs described from previous studies (Achieng et al. 2017; Al-barakah et al. 2017; Ehya and Marbouti 2016; Gu et al. 2015; Phung et al. 2015).

\section{Discriminant analysis (DA)}

Temporal DA was conducted with the same raw data set comprising 19 parameters after grouping into four clusters as obtained through the CA technique. All the measured parameters were the independent variables, while season were the dependent variable. Table 6 , displays the statistical features of DA compare with WHO standard. The results shown that the parameters such as EC, $\mathrm{SO}_{4}{ }^{2-}$, and $\mathrm{Na}^{+}$were not within the WHO guideline values for drinking water in all the samples for both seasons. Also, the parameter such as $\mathrm{Cl}^{-}, \mathrm{Fe}^{2+}, \mathrm{Mg}^{2+}$, and $\mathrm{TH}$ as well as parameter like $\mathrm{EC}$ and $\mathrm{HCO}_{3}{ }^{-}$are not within limit during dry and raining season, respectively. Table 7 shows the discriminant classification, matrix and canonical function. The $\mathrm{pH}$ demonstrates a high altitude during the dry likened with the wet season, while there are significantly high value of $\mathrm{CO}_{3}{ }^{2-}$ during the wet. $\mathrm{pH}$ is very significant since it can affect the solubility and toxicity of metals in the groundwater system. Though high $\mathrm{pH}$ can possible be washing out of $\mathrm{SO}_{4}{ }^{2-}$ and $\mathrm{Cl}^{-}$from soil layer surface and their replacement with $\mathrm{CO}_{3}{ }^{2-}$ in the matrix of the soil. The seasonal variation of $\mathrm{pH}$ values observed in this study is in agreement with the outcomes of a previous related study by Aly (2015).

Table 8 exhibits mean comparative analysis using Anova and sample $\mathrm{T}$ test from the water quality parameters. One-way ANOVA indicated the nutritive parameters (TDS, $\mathrm{NO}_{3}, \mathrm{~F}, \mathrm{Mn}, \mathrm{TH}$ and $\mathrm{SiO}_{2}$ ) are not significantly to different season $(\mathrm{p}<0.05)$. The spatial variation in water quality also was conducted to test the significance of discriminant functions obtained and to determine the most significant variables connected with differences among the spatial clusters (Fig. 3). The major features of this function are a canonical correlation of 0.998 , an eigenvalue of 325.67 , and being significant (Wilk's lambda $=0.03, \mathrm{DF}=19, \mathrm{p}<0.05)$. Regression and $\mathrm{X}$ plot was also employed for further analysis (Fig. 4). EC forecast from selected ionic compositions was equally good. The independent variables such as TDS, $\mathrm{pH}, \mathrm{AlK}, \mathrm{HCO}_{3}{ }^{-}$ and $\mathrm{SO}_{4}{ }^{2-}$ were significant in predicting $\mathrm{EC}$ value. The multiple $R 2$ value and standard errors of 0.997 and 0.56 , respectively indicates that $99.7 \%$ of the variability in EC could be attributed to the combined effect of TDS, $\mathrm{pH}$, AlK, $\mathrm{HCO}_{3}{ }^{-}$and $\mathrm{SO}_{4}{ }^{2-}$.

Meanwhile, all the independent variables were observed to have a significant effect with't' value from partial regression test at $5 \%$ level of probability on the equivalent dependent variable. In order to enhance the interpretation of these Regression and X plot groundwater model which can be used to predict the impacts of hydrological changes on the aquifer behavior was applied to the water quality parameters (Fig. 5). EC, TDS, $\mathrm{HCO}_{3}{ }^{-}$ and $\mathrm{TH}$ has significance minimum series of sequence length for which are 497.34, 468.40, 278.28 and 208.30, respectively. Season model major features are predictor number of 3 , stationary $R$ squared 0.89 , and being significant $(\mathrm{DF}=18, \mathrm{p}>0.05)$.

\section{Water quality assessment}

The Piper-trilinear plot shows the classification of water samples from various lithological environment. It also demonstrates the chemical character of the water samples using the dominant cation and anion to tell the dissimilarities and similarities of the groundwater samples. The study area water analysis result is plotted in piper diagram (Fig. 6), According to the piper diagram, the towns Kubwa and Bwari are dominant in sodium chloride type of water. The town Lugbe are dominant in the Calcium-chloride type of water. The towns Gwagwalada and Kwali are dominant in mixed type of water, which means no cations and anions exceeds 50\%. Also, the 


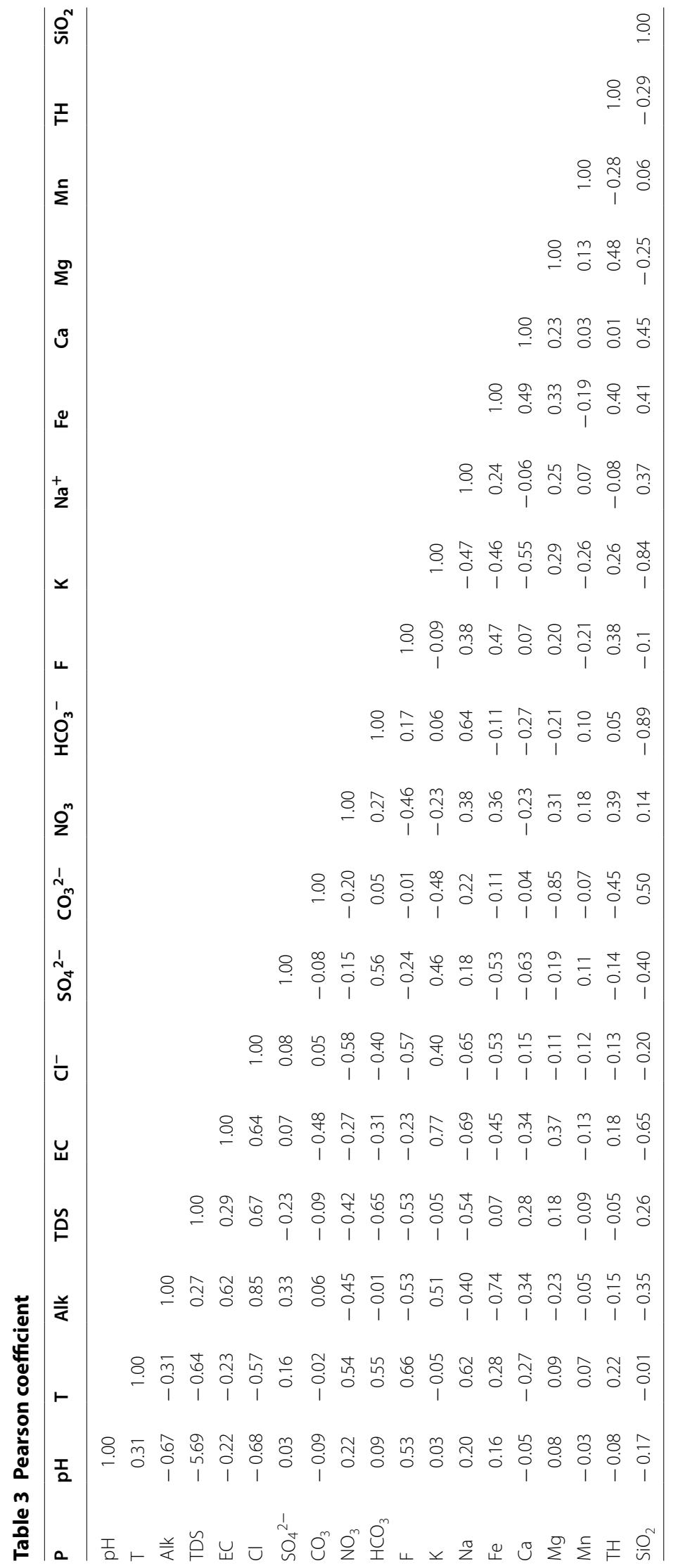




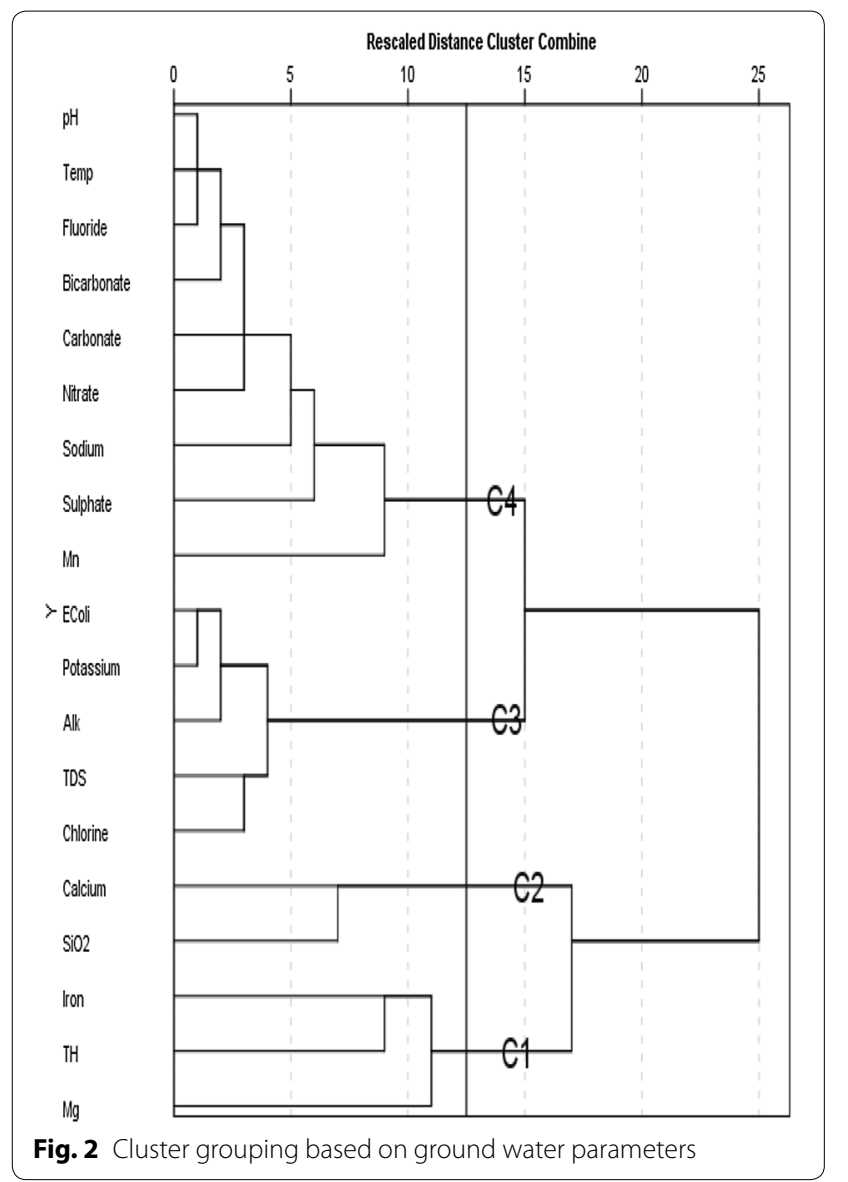

Table 4 Cluster grouping of the water quality parameters

\begin{tabular}{llll}
\hline Cluster $\mathbf{1}$ & Cluster 2 & Cluster 3 & Cluster 4 \\
\hline $\mathrm{pH}$ & $\mathrm{TDS}$ & $\mathrm{EC}$ & $\mathrm{Cl}^{-}$ \\
$\mathrm{Temp}$ & & $\mathrm{SO}_{4}{ }^{2-}$ & \\
$\mathrm{AlK}$ & $\mathrm{HCO}_{3}{ }^{-}$ & \\
$\mathrm{CO}_{3}{ }^{2-}$ & $\mathrm{Na}^{+}$ & \\
$\mathrm{NO}_{3}{ }^{-}$ & $\mathrm{TH}$ & \\
$\mathrm{F}^{-}$ & & \\
$\mathrm{K}^{+}$ & & \\
$\mathrm{Fe}^{2+}$ & & \\
$\mathrm{Ca}^{2+}$ & & \\
$\mathrm{Mg}^{2+}$ & & & \\
$\mathrm{Mn}^{2+}$ & & & \\
$\mathrm{SiO}_{2}$ & & & \\
\hline
\end{tabular}

results revealed that $16 \%$ of the samples could be classified as $\mathrm{Ca}-\mathrm{Cl}$ type, $36 \%$ of the samples as $\mathrm{Na}-\mathrm{Cl}$ type, and $48 \%$ as Mixed type. Studies including Aly (2015) and Al-Omran et al. (2015) also found comparable results by
Table 5 Hydro-chemical features of cluster grouping

\begin{tabular}{|c|c|c|c|c|c|}
\hline Parameter & Cluster 1 & Cluster 2 & Cluster 3 & Cluster 4 & WHO limit \\
\hline $\mathrm{pH}$ & 7.35 & 6.40 & 6.93 & 6.42 & $6.5-8.5$ \\
\hline Temp & 27.34 & 23.12 & 26.22 & 24.70 & NA \\
\hline AlK & 11.01 & 55.01 & 29.27 & 45.67 & NA \\
\hline TDS & 987.32 & 2112.32 & 807.74 & 1531.35 & 1000 \\
\hline $\mathrm{EC}$ & 497.34 & 3310.11 & 1343.29 & 2603.24 & 1500 \\
\hline $\mathrm{Cl}^{-}$ & 32.59 & 564.12 & 136.26 & 414.46 & 250 \\
\hline $\mathrm{SO}_{4}{ }^{2-}$ & 567.89 & 567.34 & 468.40 & 409.59 & 250 \\
\hline $\mathrm{CO}_{3}{ }^{2-}$ & 24.98 & 15.79 & 20.29 & 18.08 & NA \\
\hline $\mathrm{NO}^{3-}$ & 6.05 & 0.00 & 4.94 & 2.89 & 50 \\
\hline $\mathrm{HCO}^{3-}$ & 656.43 & 326.78 & 549.09 & 358.79 & 500 \\
\hline $\mathrm{F}^{-}$ & 1.81 & 0.47 & 1.40 & 1.07 & 1.5 \\
\hline $\mathrm{K}^{+}$ & 2.07 & 8.70 & 5.30 & 7.66 & 12 \\
\hline $\mathrm{Na}^{+}$ & 515.45 & 55.98 & 358.51 & 85.38 & 50 \\
\hline $\mathrm{Fe}^{2+}$ & 2.34 & 0.07 & 1.32 & 0.49 & 0.3 \\
\hline $\mathrm{Ca}^{2+}$ & 67.56 & 23.87 & 75.31 & 51.08 & 300 \\
\hline $\mathrm{Mg}^{2+}$ & 56.43 & 21.36 & 65.73 & 115.03 & 50 \\
\hline $\mathrm{Mn}$ & 0.04 & 0.01 & 0.03 & 0.02 & 0.4 \\
\hline $\mathrm{TH}$ & 231.67 & 213.56 & 641.16 & 505.01 & 500 \\
\hline $\mathrm{SiO}_{2}$ & 8.02 & 0.67 & 4.56 & 2.99 & NA \\
\hline
\end{tabular}

Table 6 Statistical characteristics of discriminant grouping and WHO limit

\begin{tabular}{|c|c|c|c|}
\hline \multirow[t]{3}{*}{ Parameters } & \multicolumn{3}{|c|}{ Discriminant analysis } \\
\hline & \multicolumn{2}{|c|}{ Mean and standard deviation } & \multirow[t]{2}{*}{ WHO limit } \\
\hline & Dry season & Raining season & \\
\hline $\mathrm{pH}$ & $6.67 \pm 0.67$ & $6.87 \pm 0.57$ & $6.5-8.5$ \\
\hline Temp & $25.25 \pm 1.57$ & $26.32 \pm 0.94$ & \\
\hline AIK & $31.20 \pm 18.55$ & $41.13 \pm 3.56$ & \\
\hline TDS & $1433.76 \pm 459.38$ & $519.96 \pm 64.71$ & 1000 \\
\hline $\mathrm{EC}$ & $1789.31 \pm 1040.08$ & $1811.21 \pm 526.37$ & 1500 \\
\hline $\mathrm{Cl}^{-}$ & $253.27 \pm 221.27$ & $211.14 \pm 85.83$ & 250 \\
\hline $\mathrm{SO}_{4}{ }^{2-}$ & $359.99 \pm 297.47$ & $578.08 \pm 288.70$ & 250 \\
\hline $\mathrm{CO}_{3}^{2-}$ & $17.74 \pm 9.88$ & $22.14 \pm 4.85$ & \\
\hline $\mathrm{NO}_{3}-$ & $4.13 \pm 2.64$ & $4.31 \pm 1.87$ & 50 \\
\hline $\mathrm{HCO}_{3}^{-}$ & $403.66 \pm 141.64$ & $595.97 \pm 111.17$ & 500 \\
\hline $\mathrm{F}^{-}$ & $1.23 \pm 0.54$ & $1.36 \pm 0.29$ & 1.5 \\
\hline $\mathrm{K}^{+}$ & $5.61 \pm 3.00$ & $6.97 \pm 2.01$ & 12 \\
\hline $\mathrm{Na}^{+}$ & $211.53 \pm 189.41$ & $333.17 \pm 191.13$ & 50 \\
\hline $\mathrm{Fe}^{2+}$ & $1.51 \pm 1.23$ & $0.29 \pm 0.65$ & 0.3 \\
\hline $\mathrm{Ca}^{2+}$ & $90.95 \pm 83.85$ & $30.04 \pm 17.24$ & 300 \\
\hline $\mathrm{Mg}^{2+}$ & $118.80 \pm 118.05$ & $30.49 \pm 16.90$ & 50 \\
\hline $\mathrm{Mn}$ & $0.03 \pm 0.02$ & $0.03 \pm 0.03$ & 0.4 \\
\hline $\mathrm{TH}$ & $676.92 \pm 668.83$ & $464.99 \pm 120.27$ & 500 \\
\hline $\mathrm{SiO}_{2}$ & $4.88 \pm 3.44$ & $2.65 \pm 2.36$ & \\
\hline
\end{tabular}


Table 7 Matrix, function coefficient and canonical discriminant based on water quality parameters

\begin{tabular}{lrrrr}
\hline Parameters & \multicolumn{4}{l}{ Discriminant function classification } \\
\cline { 2 - 3 } & Function & & Canonical & $\begin{array}{c}\text { Structure } \\
\text { matrix }\end{array}$ \\
\cline { 2 - 3 } & Dry season & Rain season & & \\
\hline $\mathrm{pH}$ & 1429.90 & 1350.94 & 1.41 & -0.04 \\
$\mathrm{Temp}$ & 112.59 & 79.71 & -1.27 & -0.11 \\
$\mathrm{AlK}$ & 41.07 & 51.86 & -4.47 & -0.04 \\
$\mathrm{TDS}$ & 1.19 & -0.03 & 12.42 & 0.16 \\
$\mathrm{EC}$ & -0.25 & -0.16 & -2.00 & 0.04 \\
$\mathrm{Cl}^{-}$ & 0.73 & 1.46 & -3.71 & 0.06 \\
$\mathrm{SO}_{4}{ }^{2-}$ & -0.29 & -0.49 & 1.64 & -0.05 \\
$\mathrm{CO}_{3}{ }^{2-}$ & 74.03 & 81.57 & -1.77 & -0.10 \\
$\mathrm{NO}_{3}{ }^{-}$ & 34.19 & 7.78 & 1.77 & -0.31 \\
$\mathrm{HCO}_{3}{ }^{-}$ & 0.99 & 0.96 & 0.14 & 0.13 \\
$\mathrm{~F}^{-}$ & -1229.57 & -1451.05 & 2.87 & -0.13 \\
$\mathrm{~K}^{+}$ & -281.56 & -1451.05 & -2.45 & 0.12 \\
$\mathrm{Na}^{+}$ & 0.91 & 1.38 & -2.53 & 0.04 \\
$\mathrm{Fe}^{2+}$ & 140.10 & 137.63 & 0.07 & -0.20 \\
$\mathrm{Ca}^{2+}$ & -2.59 & -1.28 & -2.46 & 0.14 \\
$\mathrm{Mg}^{2+}$ & 8.39 & 8.01 & 0.99 & 0.06 \\
$\mathrm{Mn}^{2+}$ & -7644.05 & -8120.77 & 0.30 & -0.28 \\
$\mathrm{TH}^{2}$ & 0.66 & 0.53 & 1.85 & 0.03 \\
$\mathrm{SiO}_{2}$ & -161.00 & -163.48 & 0.22 & 0.04 \\
\hline & & & &
\end{tabular}

identified major water types and their ionic composition of different groundwater water samples.

The sodium-chloride and calcium-chloride are rich in these regions because the parent rock are of Fissile Hornblende Biotite gneiss and Charnockite, which have composed of sodium and calcium rich minerals (Arulbalaji and Gurugnanam 2017).

Series and time series plot, are data visualization tools that demonstrates data points at successive intervals of time. The vertical and horizontal points on the chart corresponds to quality and time, respectively, as well as quickly identify spot, trend in cyclical pattern over a given period of time. Water analysis result from the study area is plotted in (Figs. 7 and 8), According to the piper diagram during dry season, TDS concentration has highest time series value between 1200 and $2100 \mathrm{mg} / \mathrm{l}$, while the mean and SD are 1433.76 and 459.38 , respectively. Hence, this component possible represents the influence of high organic and inorganic substances in molecular or ionized suspended form, from percolation of manmade products such as pesticides and fertilizers into the soil, road salt, toxic chemicals from underground storage tanks, used motor oil, and untreated waste from septic tanks. This in turn reduces water utility for drinking, irrigation as well as agriculture purposes.

Table 8 Mean comparative analysis obtained from the water quality parameters

\begin{tabular}{|c|c|c|c|c|c|c|}
\hline \multirow[t]{4}{*}{ Parameters } & \multicolumn{6}{|l|}{ Mean comparative test } \\
\hline & \multicolumn{3}{|l|}{ One way Anova } & \multicolumn{3}{|c|}{ One sample T test } \\
\hline & \multirow[t]{2}{*}{ Unstandardized coefficients } & \multirow[t]{2}{*}{$\mathbf{t}$} & \multirow[t]{2}{*}{ Sig. } & \multirow[t]{2}{*}{$\mathbf{t}$} & \multicolumn{2}{|c|}{$95 \%$ interval differences } \\
\hline & & & & & Lower & Upper \\
\hline $\mathrm{pH}$ & $0.18 \pm 0.51$ & 0.36 & 0.73 & 53.91 & 6.49 & 7.01 \\
\hline Temp & $0.03 \pm 0.03$ & 1.05 & 0.33 & 89.36 & 25.08 & 26.27 \\
\hline AlK & $0.01 \pm 0.00$ & 3.29 & 0.02 & 11.59 & 28.91 & 41.44 \\
\hline TDS & $-0.00 \pm 0.00$ & -12.71 & 0.00 & 9.25 & 829.89 & 1306.60 \\
\hline EC & $5.71 \mathrm{E}-05 \pm 0.00$ & 1.11 & 0.31 & 10.48 & 1443.07 & 2150.68 \\
\hline $\mathrm{Cl}^{-}$ & $0.01 \pm 0.00$ & 1.96 & 0.10 & 6.63 & 162.85 & 309.98 \\
\hline $\mathrm{SO}_{4}{ }^{2-}$ & $0.00 \pm 0.00$ & -1.56 & 0.17 & 7.26 & 320.16 & 574.30 \\
\hline $\mathrm{CO}_{3}{ }^{2-}$ & $0.01 \pm 0.01$ & 1.54 & 0.17 & 11.61 & 16.03 & 22.96 \\
\hline $\mathrm{NO}_{3}-$ & $-0.02 \pm 0.01$ & -2.23 & 0.07 & 9.04 & 3.24 & 5.16 \\
\hline $\mathrm{HCO}_{3}^{-}$ & $1.49 \mathrm{E}-05 \pm 0.00$ & 0.08 & 0.94 & 15.03 & 414.56 & 546.61 \\
\hline $\mathrm{F}^{-}$ & $-0.23 \pm 0.10$ & -2.36 & 0.06 & 14.16 & 1.09 & 1.47 \\
\hline $\mathrm{K}^{+}$ & $0.01 \pm 0.02$ & 0.74 & 0.49 & 11.44 & 5.04 & 7.26 \\
\hline $\mathrm{Na}^{+}$ & $0.00 \pm 0.00$ & 2.34 & 0.06 & 6.65 & 179.38 & 341.00 \\
\hline $\mathrm{Fe}^{2+}$ & $0.01 \pm 0.03$ & 0.23 & 0.83 & 4.28 & 0.53 & 1.51 \\
\hline $\mathrm{Ca}^{2+}$ & $0.01 \pm 0.00$ & 2.36 & 0.06 & 4.64 & 36.99 & 96.18 \\
\hline $\mathrm{Mg}^{2+}$ & $5.82 \mathrm{E}-05 \pm 0.00$ & 0.12 & 0.91 & 4.14 & 41.82 & 125.14 \\
\hline $\mathrm{Mn}$ & $-0.70 \pm 1.21$ & -0.58 & 0.59 & 5.73 & 0.02 & 0.03 \\
\hline $\mathrm{TH}$ & $-7.42 \mathrm{E}-05 \pm 0.00$ & -1.77 & 0.13 & 5.62 & 374.66 & 809.63 \\
\hline $\mathrm{SiO}_{2}$ & $-0.01 \pm 0.02$ & -0.54 & 0.61 & 6.24 & 2.67 & 5.31 \\
\hline
\end{tabular}




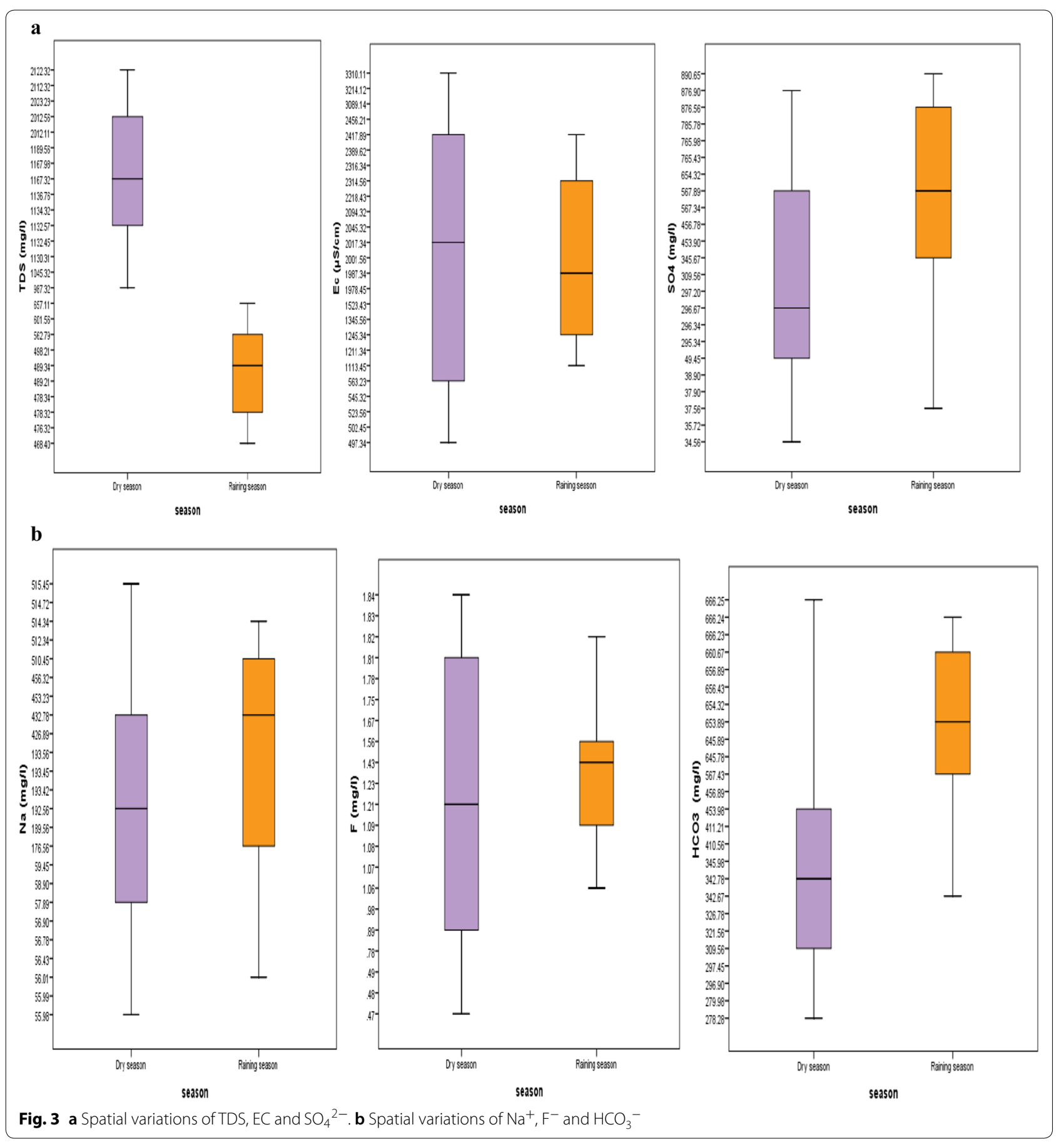

\section{Conclusions}

This study reported the microbial and chemical analyses parameters of twenty-five samples used for cooking, agricultural, drinking and domestic purposes in Abuja, Nigeria. The results revealed that the water quality parameters showed wide spatial variations with $\mathrm{pH}$ and temperature having the least variability of 5.9 and 4.5 , respectively.
Majority of the water samples (64\%) is within the slightly acidic range signifying dissolution of composite basement rocks. The very high concentration of EC in the Abuja water samples were identified as a serious source of health concern. Violations of water standards were in order of $\mathrm{Na}^{+}>\mathrm{SO}_{4}{ }^{2-}>\mathrm{EC}>\mathrm{Mg}^{2+}>\mathrm{TDS}>\mathrm{Fe}^{2+}>\mathrm{HCO}_{3}^{-}>\mathrm{F}^{-}>\mathrm{TH}>\mathrm{Cl}^{-}$, which proposes interface among sodium bearing rocks. 


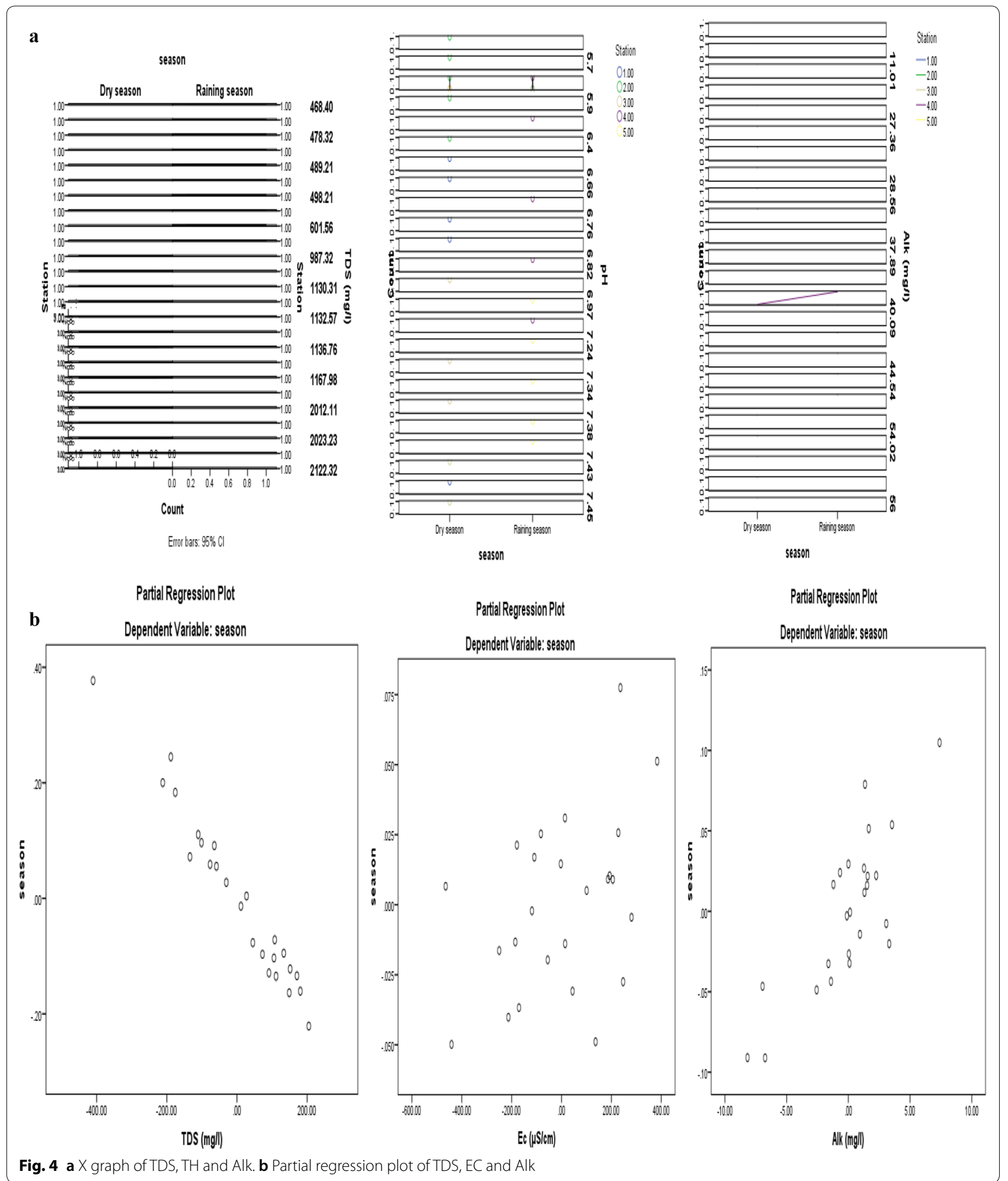

The groundwater classifications can be ranked as $\mathrm{Ca}-$ $\mathrm{Cl}<\mathrm{Na}-\mathrm{Cl}<$ Mixed types demonstrating general mixed type. Weathering, anthropogenic activities, such as waste management and agriculture as well as ion exchange, were the main sources of hydro-chemical dissimilarity in the study area. The findings of this study will be of 

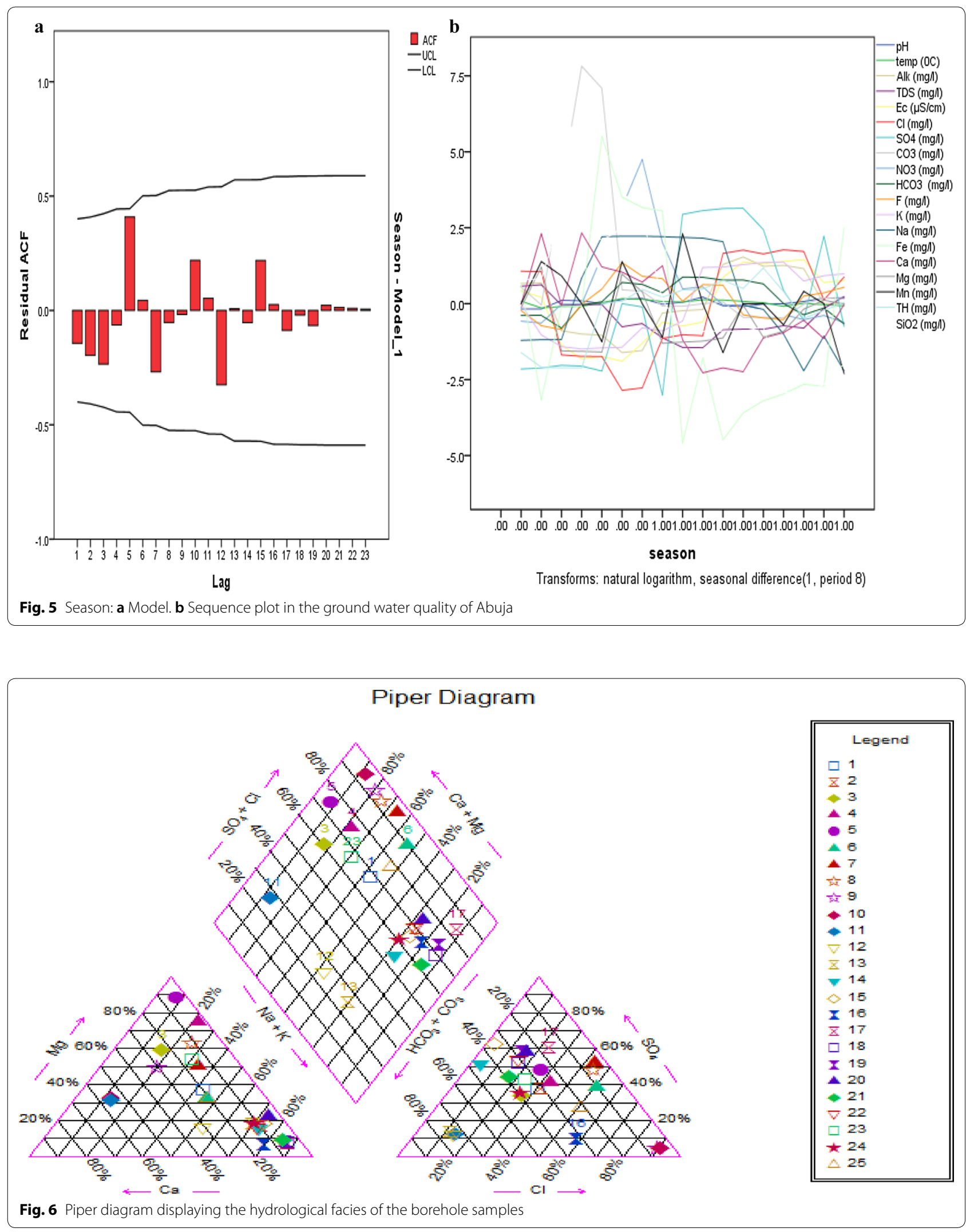


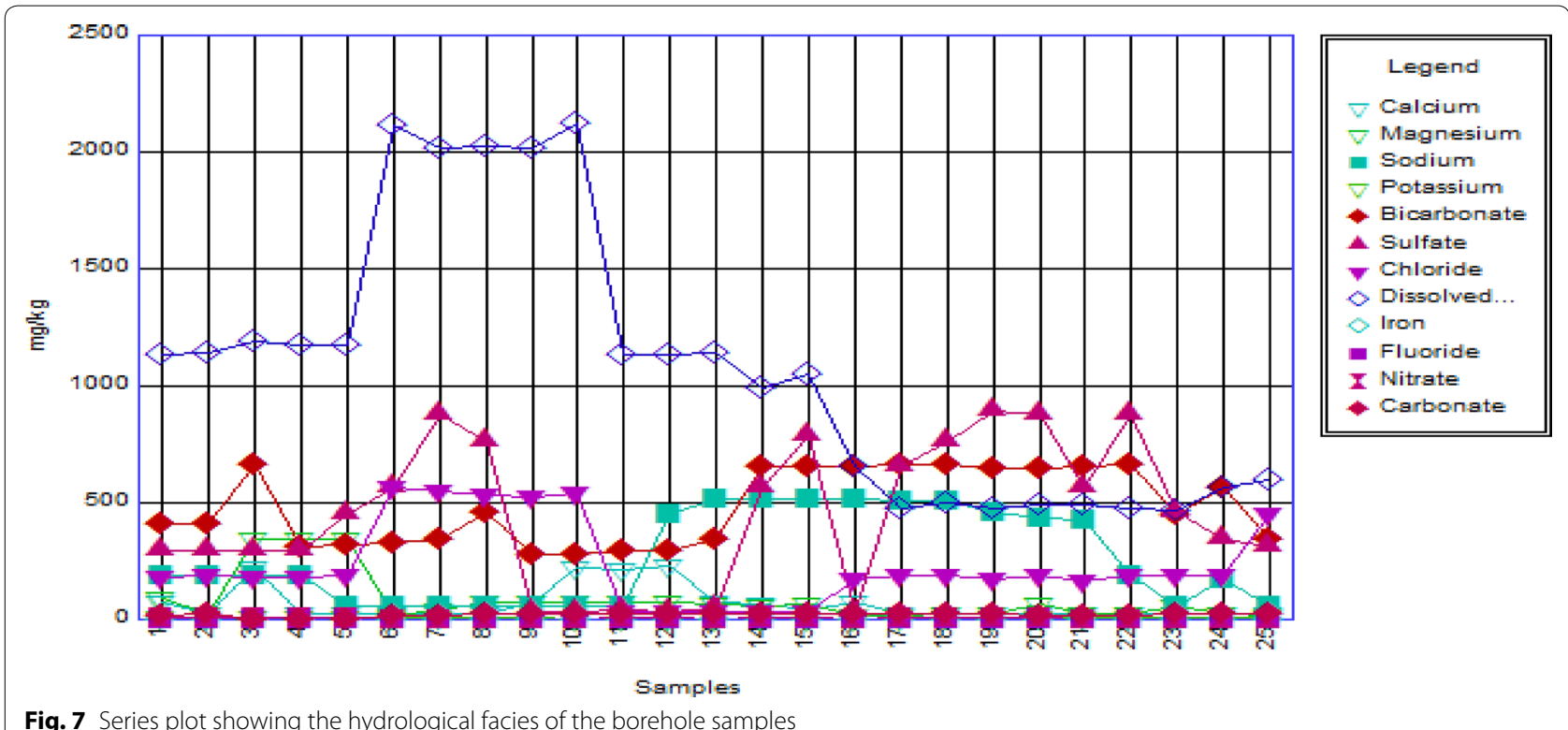

Fig. 7 Series plot showing the hydrological facies of the borehole samples

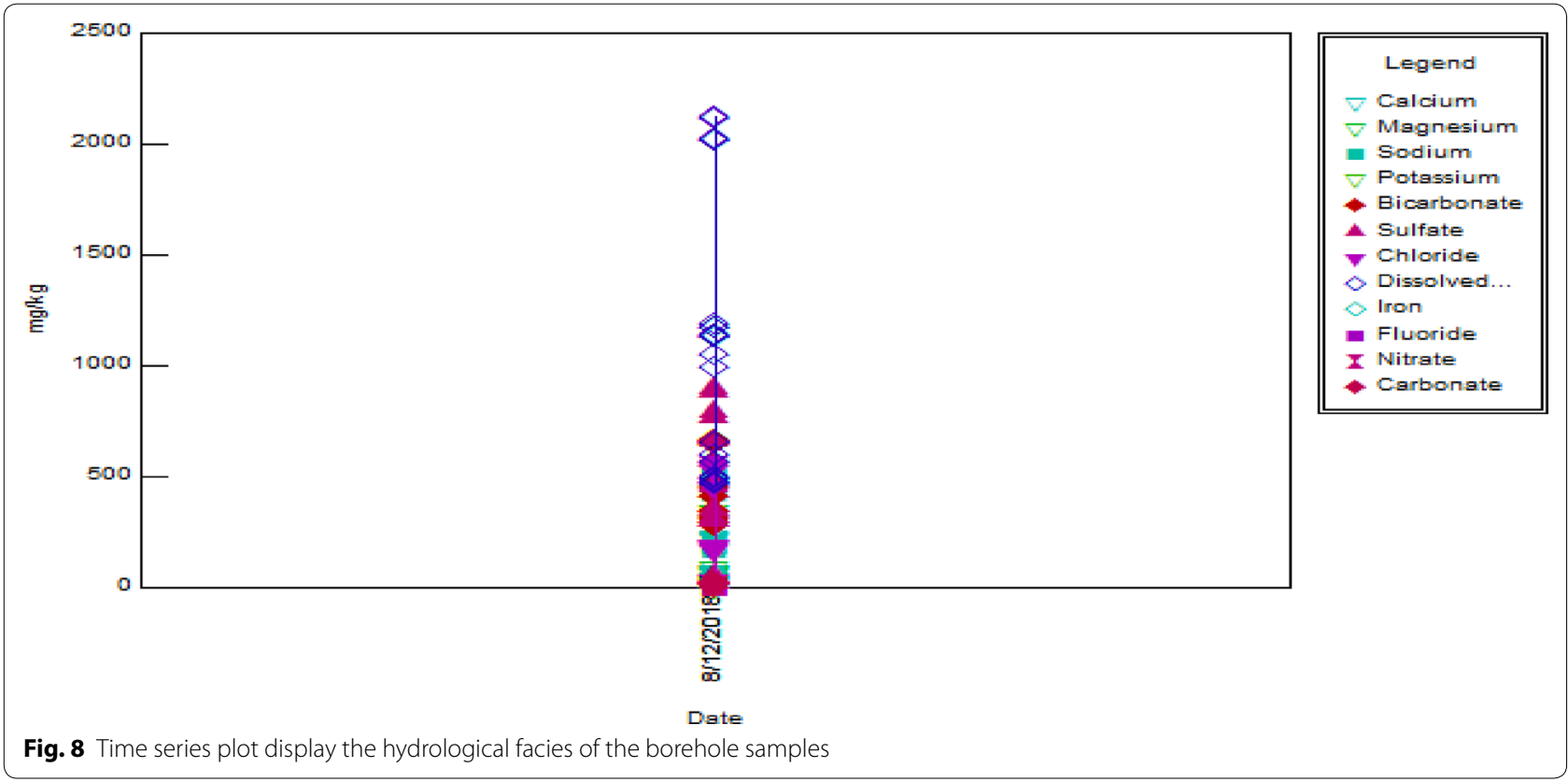

important to the water management authorities to comprehend the hydrochemistry of the groundwater components in the area for efficient and viable management.

\section{Authors' contributions}

Main author contribution about 70\%. Both authors read and approved the final manuscript.

\section{Author details}

${ }^{1}$ Department of Civil Engineering, University of Abuja, Abuja, FCT, Nigeria. ${ }^{2}$ Department of Civil Engineering, Modibbo Adama University of Technology, Yola, Adamawa State, Nigeria.

\section{Acknowledgements}

University of Lagos laboratory.

Competing interests

The authors declare that they have no competing interests.

Availability of data and materials

Applicable.

\section{Consent for publication}

Applicable.

\section{Ethics approval and consent to participate}

Not applicable. 


\section{Funding}

Not applicable.

\section{Publisher's Note}

Springer Nature remains neutral with regard to jurisdictional claims in published maps and institutional affiliations.

Received: 8 January 2019 Accepted: 8 April 2019

Published online: 30 April 2019

\section{References}

Achieng A, Raburu O, Kipkorir E, Ngodhe S. Obiero K, Ani-Sabwa J (2017) Assessment of water quality using multivariate techniques in River Sosiani, Kenya. Environ Monit Assess 189:280- 289. https://doi. org/10.1007/s10661-017-5992-5

Al-Barakah F, Abdurahman M, Aly A (2017) Water quality assessment and hydrochemical characterization of Zamzam groundwater, Saudi Arabia. Appl Water Sci 7:3985-3996. https://doi.org/10.1007/s13201-017-0549

Al-Murairi N, AbahussainA, El-Bettay A (2014) Spatialand temporal characterizations of water quality in KuwaitBay. Mar Pollut Bull 83:127-131

Al-Omran A, Al-Barakah F, Altuquq A, Aly A, Nadeem M (2015) Drinking water quality assessment and water quality index of Riyadh, Saudi Arabia. Water Qual Res J Can 50(3):287-296

Al-Tabbal JA, Kamel K (2012) Suitability assessment of groundwater for irrigation and drinking purpose in the Northern Region of Jordan. J Environ Sci Technol 5(2):274-290. https://doi.org/10.3923/jest.2012.274.290

Aly A (2015) Hydrochemical characteristics of Egypt western desert oases groundwater. Arab J Geosci 8:7551-7564

APHA (2005) Standard methods for the examination of water and wastewater. 21st ed. Washington D.C.: American Public Health Association. https:// books.google.co.uk/books/about/StandardMethodsfortheExaminati on_of.html?id=buTn1 rmfSI4C\&redir_esc=y. Accessed 20 Oct 2018

Arulbalaji P, Gurugnanam B (2017) Groundwater quality assessment using geospatial and statistical tools in Salem District, Tamil Nadu. India Appl Water Sci 7(1):2737-2751. https://doi.org/10.1007/s13201-016-0501-5

Azhar S, Ahmad ZA, Mohd KY, Mohammad FR, Hafizan J (2015) Classification of river water quality using multivariate analysis. Procedia Environ Sci 30(1):79-84. https://doi.org/10.1016/j.proenv.2015.10.014

Cao Y, Tang C, Song X, Liu C, Zhang Y (2016) Identifying the hydro chemical characteristics of rivers and groundwater by multivariate statistical analysis in the Sanjiang Plain, China. Appl Water Sci 6:169-178

Chen X, Zhou WQ, Pickett STA, Li WF, Han LJ, Ren YF (2016) Diotoms are better indicators of urbanstream conditions: a case study in Beijing, China. Ecol Ind 60:265-274

Das S, Nag S (2017) Application of multivariate statistical analysis concepts for assessment of hydrogeochemistry of groundwater-a study in Suri I and II blocks of Birbhum District, West Bengal, India. Appl Water Sci 7:873-888. https://doi.org/10.1007/s13201-015-0299-6

Ehya F, Marbouti Z (2016) Hydrochemistry and contamination of groundwater resources in the Behbahan plain, SW Iran. Environ Earth Sci 75(1):455-464

Emenike CP, Tenebe IT, Omole DO, Ngene BU, Oniemayin BI, Maxwell O, Onoka BI (2017) Accessing safe drinking water in sub-Saharan Africa: issues and challenges in south-west Nigeria. Sustain Cities Soc 30:263-272. https:// doi.org/10.1016/j.scs.2017.01.005

Enitan I, Enitan A, Odiyo J, Alhassan M (2018) Human health risk assessment of trace metals in surface water due to leachate from the municipal dumpsite by pollution index: a case study from Ndawuse River, Abuja, Nigeria. Open Chem 16 (1):214-227. https://doi.org/10.1515/chem-2018-0008
Etteieb S, Cherif S, Tarhouni J (2017) Hydrochemical assessment of water quality for irrigation: a case study of the Medjerda River in Tunisia. Appl Water Sci 7:469-480. https://doi.org/10.1007/s13201-015-0265-3

Fijani E, Moghaddam A, Tsai F, Tayfur G (2017) Analysis and assessment of hydro chemical characteristics of Maragheh-Bonab plain aquifer, northwest of Iran. Water Resour Manag 31(3):765-780. https://doi.org/10.1007/ s11269-016-1390

Fingl E (1980) Laxatives and cathartics. In: Gilman AG et al (eds) Pharmacological basis of Therapeutics. New York, NY, MacMillan Publishing

Gu Q, Wang H, Zheng N, Zhu W, Li K (2015) Ecological footprint analysis for urban agglomeration sustainability in the middle stream of Yangtze River. Ecol Model 318:86-99

Islam SMD-U, Bhuiyan MAH, Rume T, Azam G (2017) Hydrogeochemical investigation of groundwater in shallow coastal aquifer of Khulna District, Bangladesh. Appl Water Sci 7:1-18. https://doi.org/10.1007/s1320 1-017-0533-5

Khound J, Bhattacharyya G (2016) Multivariate statistical evaluation of heavy metals in the surface water sources of Jia Bharali river basin, North Brahmaputra plain, India. Appl Water Sci 7(5):2577-2586. https://doi. org/10.1007/s13201-016-0453-9

Li P (2016) Groundwater quality in Western China: challenges and paths forward for groundwater quality research in Western China. Expo Health 8:305-310

Li P, Qian H, Wu J, Zhang Y, Zhang H (2013) Major ion chemistry of shallow groundwater in the Dongsheng coalfield, Ordos Basin, China. Mine Water Environ 32(3):195-206. https://doi.org/10.1007/s10230-013-0234-8

Li Y, Li Y, Qureshi S, Kappas M, Hubacek K (2015) On the relationship between landscape ecological patterns and water quality across gradient zones of rapid Urbanization in coastal China. Ecol Model 318:100-108

Ojekunle Z, Ojekunle V, Adeyemi A, Taiwo A, Sangowusi R, Taiwo A, Adekitan A (2016) Evaluation of surface water quality indices and ecological risk assessment for heavy metals in scrap yard neighbor hood. Springer plus, 5: 560-570 https://doi.org/10.1186/s40064-016-2158-9

Phung D, Cunrui H, Shannon R, FebiD Cordia C, Xiaoming W, Minh N, Nga N, Cuong D, Trung H, Tuan D (2015) Temporal and spatial assessment of river surface water quality using multivariate statistical techniques: a study in Can Tho City, a Mekong Delta area, Vietnam. Environ Monit Assess 187(1):229-238. https://doi.org/10.1007/s10661-015-4474

Raman S, Geetha G (2005) Correlation analysis and prediction of characteristics parameters and water quality index of ground Water. Pollut Res 24:197-200

Sreedhar ANY, Mohammad AT, Sayadi H (2016) Water quality analysis of the Rapur area, Andhra Pradesh, South India using multivariate techniques. Appl Water Sci 7(6):2767-2777. https://doi.org/10.1007/s1320 1-016-0504-2

WHO, UNICEF (2014) Progress on sanitation and drinking water-2014 update. Monitoring programme for water supply and sanitation. ISBN 9789241507240

\section{Submit your manuscript to a SpringerOpen ${ }^{\odot}$ journal and benefit from:}

- Convenient online submission

- Rigorous peer review

- Open access: articles freely available online

- High visibility within the field

- Retaining the copyright to your article

Submit your next manuscript at $\boldsymbol{\nabla}$ springeropen.com 